\title{
RANCANG BANGUN SISTEM INFORMASI KOPERASI KARYAWAN PADA BADAN PUSAT STATISTIK (BPS) KOTA BENGKULU
}

\author{
Sapri $^{1}$, Rizka Tri Alinse ${ }^{2}$ \\ ${ }^{1,2}$ Program Studi Teknik Informatika, Fakultas Ilmu Komputer, Universitas Dehasen \\ Jalan Meranti Raya No.32 Kelurahan Sawah Lebar Kota Bengkulu Telp. 22027 Fax. (0736) 341139 \\ ${ }^{1}$ sapriukubaru@yahoo.co.id \\ ${ }^{2}$ rizkatri07@gmail.com
}

\begin{abstract}
Abstrak: Koperasi adalah badan hukum yang didirikan oleh orang perseorangan atau badan hukum koperasi, dengan pemisahan kekayaan para anggotanya sebagai modal untuk menjalankan usaha, yang memenuhi aspirasi dan kebutuhan bersama di bidang ekonomi, sosial, dan budaya sesuai dengan nilai dan prinsip koperasi. Dukungan infrastruktur komputer pada Koperasi Badan Pusat Statistik (BPS) Kota Bengkulu yang ada saat ini telah dapat dimanfaatkan dengan baik. Salah satu alternatifnya dengan dikembangkannya Sistem Informasi Koperasi Karyawan pada Koperasi pada Badan Pusat Statistik (BPS) dalam upaya membantu pegawai dalam mengelola data-data terdiri dari data anggota, data pengajuan pinjaman, data pengajuan disetujui, data simpanan pinjaman dan data angsuran. Tujuan yang hendak dicapai dalam penelitian ini adalah untuk membuat Rancang Bangun sistem Informasi Koperasi Karyawan Pada Badan Pusat Statistik (BPS) Kota Bengkulu menggunakan bahasa pemrograman Visual Basic 6.0. Metode penelitian yang digunakan dalam penelitian ini adalah dari sistem konvensional menjadi sistem komputer dengan tahapannya adalah analisis sistem lama, analisis sistem baru, perancangan sistem, implementasi sistem dan uji coba sistem. Perangkat lunak yang digunakan dalam pembuatan adalah menggunakan Rancang Bangun sistem Informasi Koperasi Karyawan Pada Badan Pusat Statistik (BPS) menggunakan Visual Basic 6.0.Hasil yang diharapkan dari Rancang Bangun sistem Informasi Koperasi Karyawan Pada Badan Pusat Statistik (BPS) adalah adanya laporan-laporan yang dapat dicetak kedalam lembar kerja berupa laporan daftar anggota koperasi, laporan data simpanan per anggota, laporan data pinjaman per anggota laporan data angsuran per anggota dan rekapitulasi pinjaman anggota.
\end{abstract}

Kata Kunci: Sistem Informasi, Koperasi, Visual Basic 6.0.

Abstract: Cooperative is a legal entity established by individuals or legal entities cooperatives, with the separation of the wealth of its members as capital to run the business, which meet the aspirations and principles of cooperatives. Support computer infrastructure at the Cooperative Central Statistics Agency (BPS) Bengkulu city that exists today has been able to put to good use. One alternative with the development of information Systems Employees Cooperative Central Statistic Agency (BPS) of Bengkulu in an effort to help empoyees manage the data consists of data members, a data clerk, data submitted by the loan, the loan is approved the data, the data stores and data loan installment. Goals to be achieved in this research is to make the Design of Cooperative Information System Employees at the Central Statistic Agency (BPS) of Bengkulu using the prohramming language Visual Basic 6.0. The method used in this study is from the conventional system into the computer system with its stages is the analysis of the old system, the new system analysis, system design, system implementation and system testing. The software used in the manufacture of Cooperative Information System Employees at the Central Statistic Agency (BPS) Bengkuluareusing Visual Basic 6.0. The expected result of the information System Cooperative Information System Employees at the Central Statistic Agency (BPS) of Bengkulu are the reports which can be molded into a worksheet in the form of a report listing the cooperative members, data reports savings per member, report lending data per member, data reports installment per member and recapitulation member loans.

Keywords: Information systems, Cooperative, Visual Basic 6.0. 
Jurnal Pseudocode, Volume V Nomor 2, September 2018, ISSN 2355-5920, e-ISSN 2655-1845 www.ejournal.unib.ac.id/index.php/pseudocode

\section{PENDAhUluan}

Seiring dengan perkembangan ilmu pengetahuan dan teknologi, keinginan-keinginan kita juga meningkat baik terhadap diri sendiri maupun orang lain. Teknologi komputer memegang peranan yang sangat penting kesehatan, perbankan, transportasi, rekayasa perangkat lunak, rekayasa genetika maupun bidang lainnya. Salah satu faktor pendukung semakin berkembangnya teknologi yaitu telah dimanfaatkan berbagai bahasa pemrograman dalam mendukung kinerja manusia. Visual Basic 6.0 merupakan salah satu bahasa pemrograman popular yang saat ini telah dimanfaatkan dalam berbagai instansi baik pemerintahan maupun swasta dalam menyelesaikan berbagai persoalan pekerjaannya.

Kantor Badan Pusat Statistik (BPS) Kota Bengkulu saat ini telah memiliki badan usaha dalam bentuk koperasi karyawan Koperasi karyawan pada Badan Pusat Statistik (BPS) Kota Bengkulu bergerak dalam bidang simpan pinjam bagi anggotanya. Dalam menjalankan usaha simpan pinjam dilakukan dengan system terbuka dan keanggotan hanya terbatas pada karyawan yang ada pada Kantor Koperasi Badan Pusat Statistik (BPS) Kota Bengkulu. Koperasi Karyawan pada Badan Pusat Statistik (BPS) Kota Bengkulu saat ini terus mengembangkan usaha dengan cara memberikan kemudahan bagi anggota baru untuk menjadi anggota melalui berbagai usaha dengan cara melakukan pinjaman kepada anggotanya.

Sarana pendukung berupa peralatan komputer saat ini telah tersedia dalam usaha menunjang kinerja pengurus Koperasi Badan Pusat Statistik (BPS) Kota Bengkulu dalam mengelola anggota koperasinya. Namun demikina, dalam kegiatan peminjaman dan pembayaran angsuran pinjaman oleh anggota saat ini masih dilakukan secara konvensional yaitu proses pencatatan secara manual dan belum menggunakan aplikasi khusus dalam menunjang kinerjanya. Pencatatan manual dilakukan terhadap anggota koperasi yang ada pada Koperasi Badan Pusat Statistik (BPS) Kota Bengkulu, peminjaman yang dilakukan oleh anggota maupun pembayaran angsuran yang dilakukan oleh anggota koperasi. Setelah proses pencatan dilakukan ke dalam buku-buku keuangan koperasi, kemudian secara manual terhadap catatan-catatan tersebut dilakukan pengelolaan dengan menggunakan aplikasi Microsoft Excel.

Berangkat dari masalah tersebut, salah satu solusi yang dapat dilakukan pada Badan Pusat Statistik (BPS) Kota Bengkulu adalah dengan melakukan perbaikan kinerja dalam bentuk pembuatan aplikasi khusus karena itu penulis mengangkat judul "Rancang Bangun Sistem Informasi Koperasi Karyawan Pada Badan Pusat Statistik (BPS) Kota Bengkulu”.

\section{LANDASAN TEORI}

\section{A. Pengertian Rancang Bangun}

Menurut Kamus Besar Bahasa Indonesia, kata rancang berarti mengatur sesuatu sebelum bertindak, mengerjakan atau melakukan sesuatu untuk direncanakan. Sedangkan kata bangun berarti sesuatu yang didirikan (Departemen Pendidikan Nasional, 2002). Rancang bangun berarti merencanakan atau mendesain sesuatu yang akan dibuat (Departemen Pendidikan Nasional, 2002).

\section{B. Pengertian Sistem}

Sistem merupakan: 1) kumpulan dari bagianbagian yang bekerjasama untuk mencapai tujuan yang sama, 2) sekumpulan objek-objek yang saling berelasi dan berinteraksi serta hubungan objek bisa 
Jurnal Pseudocode, Volume VI Nomor 1, Februari 2019, ISSN 2355-5920, e-ISSN 2655-1845 www.ejournal.unib.ac.id/index.php/pseudocode

dilihat sebagai satu kesatuan yang dirancang untuk mencapai satu tujuan [1].

Suatu sistem adalah jaringan kerja dari prosedur-prosedur, berkumpul bersama-sama untuk melakukan suatu kegiatan atau menyelesaikan suatu sasaran tertentu [2]. Suatu sistem yang baik harus mempunyai tujuan dan sasaran yang tepat karena hal itu sangat menentukan dalam mendefinisikan masukan yang dibutuhkan sistem dan juga keluaran yang dihasilkan. Sistem juga merupakan kumpulan elemen-eleman yang saling terkait dan bekerjasama untuk memproses masukan (input) yang ditujukan kepada sistem tersebut dan mengolah masukan tersebut sampai menghasilkan keluaran (output) yang diinginkan.

\section{Pengertian Sistem Informasi}

Sebuah sistem informasi merupakan kumpulan dari perangkat keras dan perangk lunak komputer serta perangkat manusia yang akan mengolah data menggunakan perangkat lunak tersebut. Selain itu data juga memegang peranan yang penting dalam sistem informasi [2]. Data yang akan dimasukkan adalah sebuah sistem informasi dapat berupa formulir-formulir, prosedur-prosedur dan bentuk data lainnya.

Selain itu sistem informasi dapat didefinisikan sebagai berikut:

1. Suatu sistem yang dibuat oleh manusia yang terdiri dari komponen-komponen dalam organisasi untuk mencapai suatu tujuan yaitu menyajikan informasi.

2. Sekumpulan prosedur organisasi yang pada saat dilaksanakan akan memberikan informasi bagi pengambil keputusan dan atau untuk mengendalikan organisasi.
3. Suatu sistem didalam suatu organisasi yang mempertemukan kebutuhan pengolahan transaksi, mendukung operasi, bersifat manajerial, dan kegiatan dari suatu organisasi dan menyediakan pihak luar tertentu dengan laporan-laporan yang diperlukan.

\section{Tinjauan Umum Koperasi}

Menurut Undang-Undang Nomor 17 Tahun 2012 di Pasal 1 Ayat 1 disebutkan "Koperasi adalah badan hukum yang didirikan oleh orang perseorangan atau badan hukum koperasi, dengan pemisahan kekayaan para anggotanya sebagai modal untuk menjalankan usaha, yang memenuhi aspirasi dan kebutuhan bersama di bidang ekonomi, sosial, dan budaya sesuai dengan nilai dan prinsip koperasi" [3].

Secara faktual, Undang-Undang Nomor 17 Tahun 2012 menjadi landasan hukum bagi pengembangan ekonomi kerakyatan dan demokrasi ekonomi berdasarkan Pancasila dan UUD 1945, mempertegas kedudukan koperasi sebagai badan hukum, peneguhan tehadap azas dan tujuan koperasi, pengukuhan nilai prisip sebagai jati diri koperasi Indonesia, penguatan dalam pelayanan terhadap anggota, kreativitas pengembangan modal koperasi, peningkatan fungsi pengawasan dan pembentukan lembaga pengawas KSP, peran pemerintah pusat dan daerah, menjamin simpanan anggota (LPS-KSP), serta penguatan lembaga gerakan koperasi dan kemandirian Dekopin.

Persyaratan untuk menjadi anggota dan melakukan pinjaman koperasi pada kantor Badan Pusat Statistik (BPS) terdiri:

1. Keanggotaan koperasi bersifat sukarela dan terbuka bagi PNS dalam lingkungan Anggota Badan Pusat Statistik (BPS). 
Jurnal Pseudocode, Volume V Nomor 2, September 2018, ISSN 2355-5920, e-ISSN 2655-1845 www.ejournal.unib.ac.id/index.php/pseudocode

2. Batas maxsimum pinjaman dalam sekali pengajuan adalah Rp.5.000.000,-

3. Membayar simpanan wajib sebesar Rp. 35.000,-/bulan

4. Membayaran simpanan pokok sebesar Rp. 25.000

5. Suku bunga pinjaman $2 \%$ per bulan.

6. Angsuran pinjaman dilakukan maxsimum selama 10 bulan.

\section{E. Tinjauan Umum Perangkat Keras (Hardware)}

Perangkat keras atau hardware merupakan sekumpulan perangkat keras suatu perangkat yang ada di dalam komputer. Hardware atau perangkat keras merupakan salah satu elemen dari sistem komputer yang bisa dilihat dan diraba oleh manusia secara langsung dan mendukung proses komputerisasi.

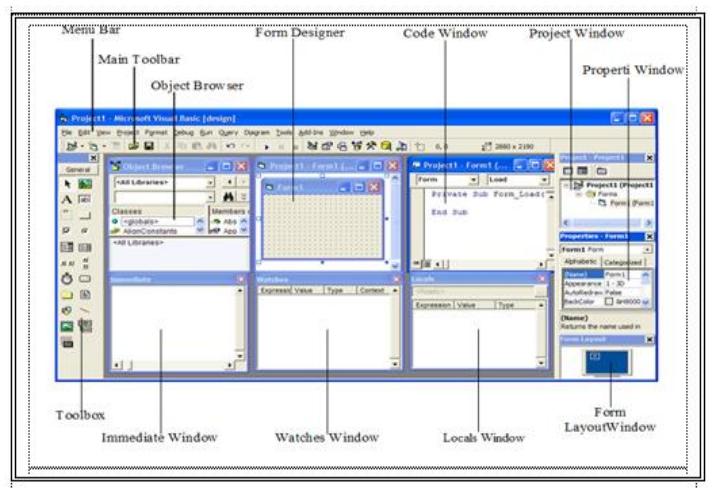

Gambar 1. Tampilan IDE Visual Basic

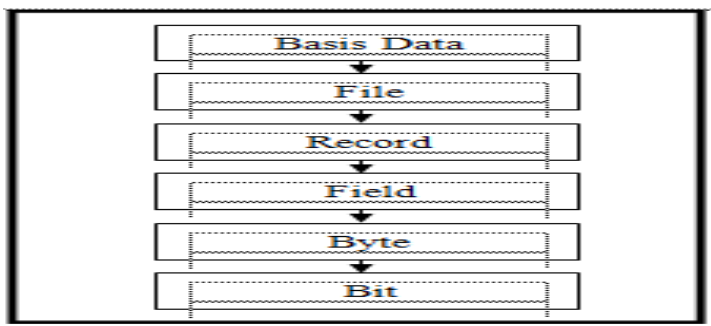

Gambar 2. Hirarki Data

\section{Metodologi Penelitian}

Metode penelitian yang penulis gunakan pada pembuatan Rancang Bangun Sistem Informasi
Koperasi Karyawan Pada Badan Pusat Statistik (BPS) Kota Bengkulu adalah dari sistem manual maupun konvensional menjadi elektronik sistem. Tahapan sistem informasi dalam metode penelitian ini adalah Analisis Sistem, Analisis Sistem Baru, Perancangan Sistem, Implementasi Sistem dan Uji Coba Sistem.

\section{HASIL DAN PEMBAHASAN}

\section{A. Tampilan Menu Login Sistem}

Menu login sistem merupakan suatu menu atau halaman yang digunakan sebagai proses autentikasi pengguna yang menjalankan program Rancang Bangun Sistem Informasi Koperasi Karyawan Pada Badan Pusat Statistik (BPS) Kota Bengkulu. Sebelum dapat menjalankan Rancang Bangun Sistem Informasi Koperasi Karyawan Pada Badan Pusat Statistik (BPS) Kota Bengkulusecara menyeluruh, seorang pengguna (admin) terlebih dahulu harus melakukan proses Login. Tampilan login Rancang Bangun Sistem Informasi Koperasi Karyawan Pada Badan Pusat Statistik (BPS) Kota Bengkulu seperti terlihat pada Gambar 3.

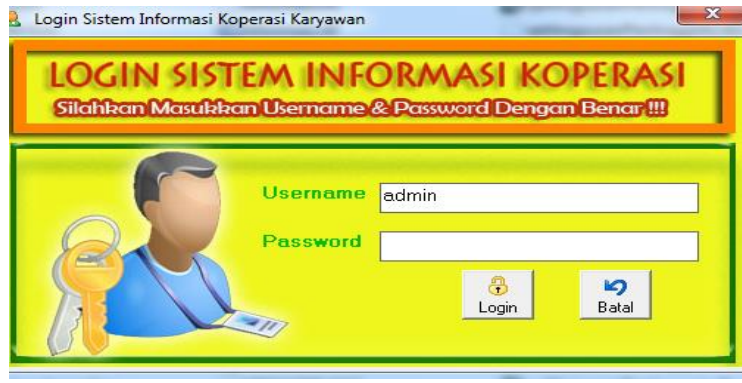

Gambar 3. Tampilan Login Sistem Admin 
Jurnal Pseudocode, Volume VI Nomor 1, Februari 2019, ISSN 2355-5920, e-ISSN 2655-1845 www.ejournal.unib.ac.id/index.php/pseudocode

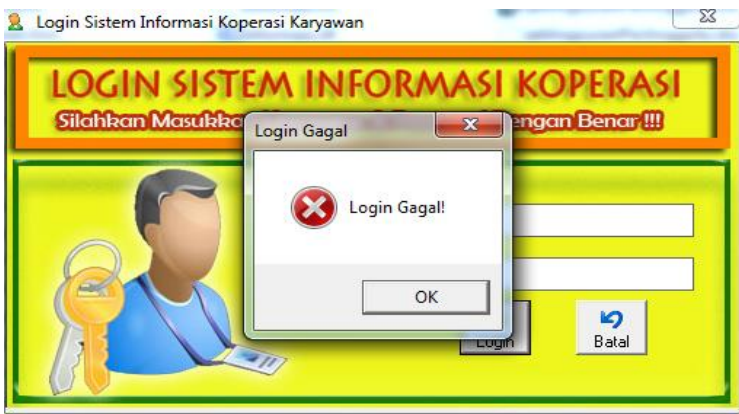

Gambar 4. Tampilan Login Gagal Admin

\section{B. Halaman Menu Utama}

Halaman menu utama merupakan suatu halaman yang menampilkan secara keseluruhan dari Rancang Bangun Sistem Informasi Koperasi Karyawan Pada Badan Pusat Statistik (BPS) Kota Bengkuluyang telah dibuat.Tampilan menu utama seperti terlihat pada Gambar 5 di bawah ini:

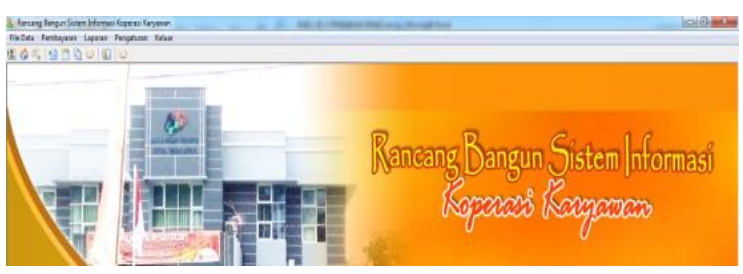

Gambar 5. Halaman Menu Utama

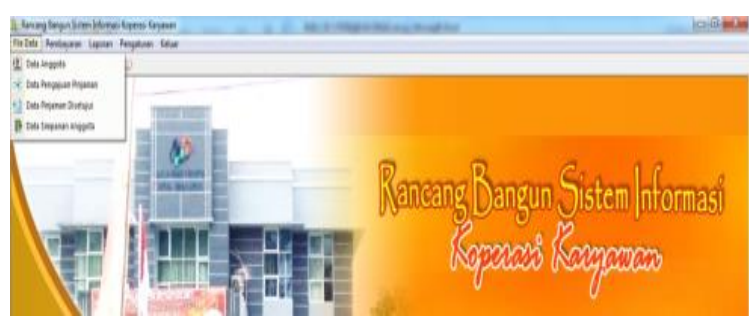

Gambar 6. Halaman Sub Menu FileData

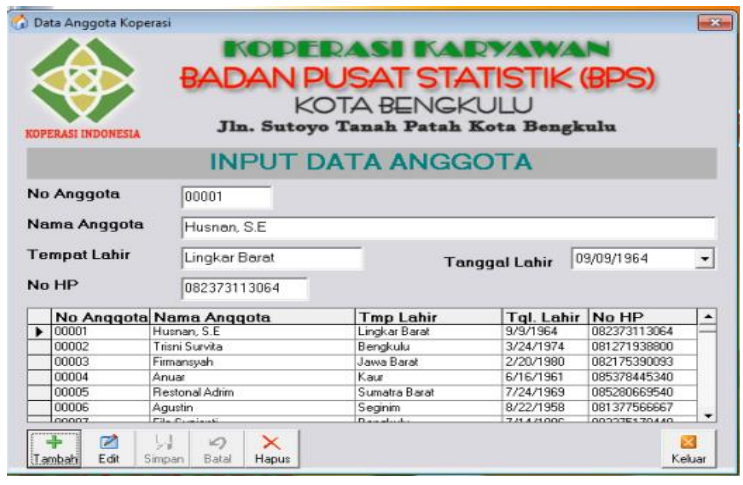

Gambar 7. Halaman Input Data Anggota

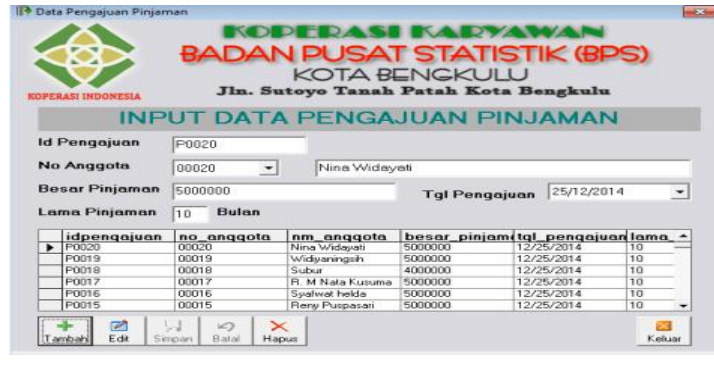

Gambar 8. Halaman Input Data Pengajuan Pinjaman

\section{Tampilan Menu Pembayaran}

Menu Pembayaran merupakan menu yang penting, dimana pada sub menu pembayaran digunakan untuk mengentrikan atau memasukkan data pembayaran koperasi yang dilakukan oleh anggota koperasi yang ada pada Badan Pusat Statistik (BPS) Kota Bengkulu dan yang berhubungan dengan dengan Rancang Bangun Sistem Informasi Koperasi Karyawan Pada Badan Pusat Statistik (BPS) Kota Bengkulu. Menu Pembayaran pada sistem informasi yang dibuat saat ini memiliki 1 (satu) sub menu terdiri dari : sub menu Angsuran seperti seperti terlihat pada Gambar 9 di bawah ini:

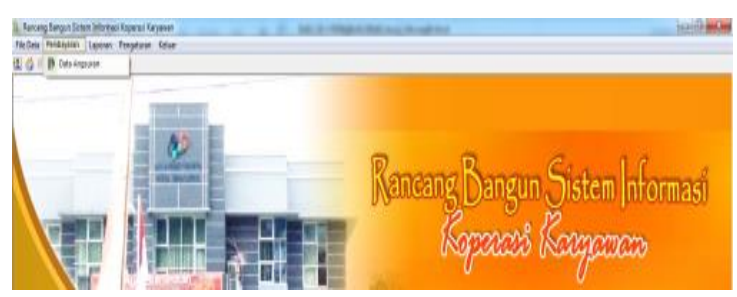

Gambar 9. Halaman Sub Menu Pembayaran

\section{Mепu Laporan}

Menu laporan pada Rancang Bangun Sistem Informasi Koperasi Karyawan Pada Badan Pusat Statistik (BPS) Kota Bengkulu merupakan menu yang digunakan untuk menampilkan laporan yang siap dicetak kedalam lembar kertas kerja hasil dari pengolah data. Pada menu laporan pada Rancang Bangun Sistem Informasi Koperasi Karyawan Pada Badan Pusat Statistik (BPS) Kota Bengkulu 
Jurnal Pseudocode, Volume V Nomor 2, September 2018, ISSN 2355-5920, e-ISSN 2655-1845 www.ejournal.unib.ac.id/index.php/pseudocode

ini, memiliki sub menu terdiri dari 5 (lima) sub menu yaitu : sub menu Laporan Daftar Anggota Koperasi, Laporan Data Simpanan Per Bulan, Laporan Data Pinjaman Per Anggota, Laporan Data Angsuran Per Anggota dan Rekapitulasi Pinjaman Koperasi Karyawan yang masingmasing menu berfungsi untuk menampilkan hasil pengolah data Rancang Bangun Sistem Informasi Koperasi Karyawan Pada Badan Pusat Statistik (BPS) Kota Bengkulu. Tampilan menu laporan pada Rancang Bangun Sistem Informasi Koperasi Karyawan Pada Badan Pusat Statistik (BPS) Kota Bengkulu seperti terlihat pada Gambar 10.

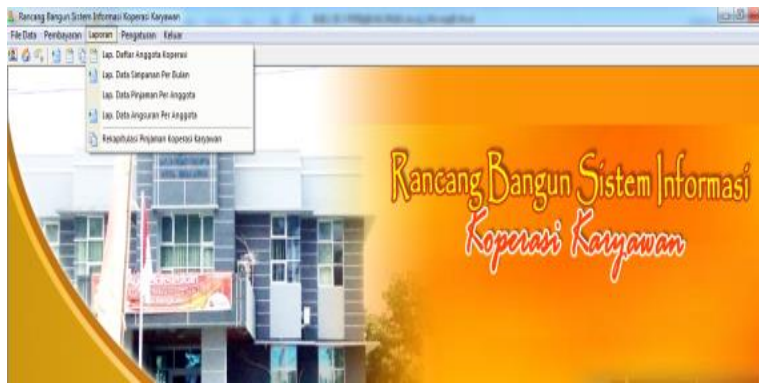

Gambar 10. Halaman Menu Laporan

\section{E. Sub Menu Pengaturan}

Sub menu pengaturan merupakan menu yang digunakan untuk menambah, menghapus maupun meng-edit daftar admin yang dapat menjalankan Rancang Bangun Sistem Informasi Koperasi Karyawan Pada Badan Pusat Statistik (BPS) Kota Bengkulu. Pada sub menu setting memiliki 1 (satu) sub menu admin yang digunakan sebagai menu input data admin. Tampilan menu pengaturan pada Rancang Bangun Sistem Informasi Koperasi Karyawan Pada Badan Pusat Statistik (BPS) Kota Bengkulu seperti terlihat pada Gambar 11.

\section{F. Kompilasi Sistem}

Rancang Bangun Sistem Informasi Koperasi Karyawan Pada Badan Pusat Statistik (BPS) Kota Bengkulu dibuat dalam upaya menciptakan aplikasi yang dapat membantu efisiensi dan efektivitas pekerjaan yang ada pada Koperasi Badan Pusat Statistik (BPS) Kota Bengkulu terutama membantu pengurus koperasi dalam mengelola data koperasi. Setelah sistem informasi selesai dibuat dengan terlebih dahulu menguji semua komponen baik menu input, tombol button yang ada didalam sistem, hasil program berupa laporan serta kode-kode (script) yang ada didalam sistem, langkah selanjutnya adalah melakukan kompilasi terhadap sistem yang telah dibuat.

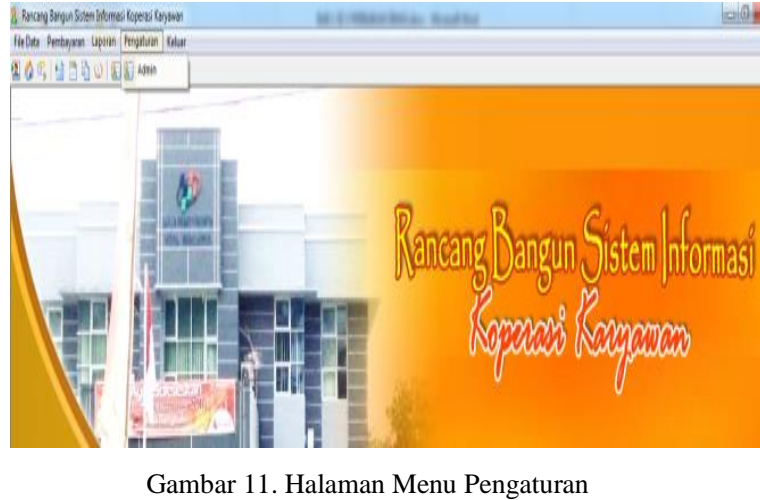

Kompilasi merupakan suatu proses membuat file aplikasi dalam bentuk file EXE (executable), sehingga dapat dijalankan secara langsung. Adapun langkah yang untuk mengkompilasi Rancang Bangun Sistem Informasi Koperasi Karyawan Pada Badan Pusat Statistik (BPS) Kota Bengkulu adalah sebagai berikut:

1. Dalam keadaan Project Sistem Informasi aktif atau terbuka, buka Form Login seperti terlihat pada Gambar 12 apabila ingin menjalankan sistem.

2. Klik menu Tool $\gg$ Publish $\gg$ Build Outputs, sehingga muncul jendela Introduction, beri centang (checklist) Skip this screen in the future dan klik tombol Next seperti terlihat pada Gambar 13. 
Jurnal Pseudocode, Volume VI Nomor 1, Februari 2019, ISSN 2355-5920, e-ISSN 2655-1845 www.ejournal.unib.ac.id/index.php/pseudocode

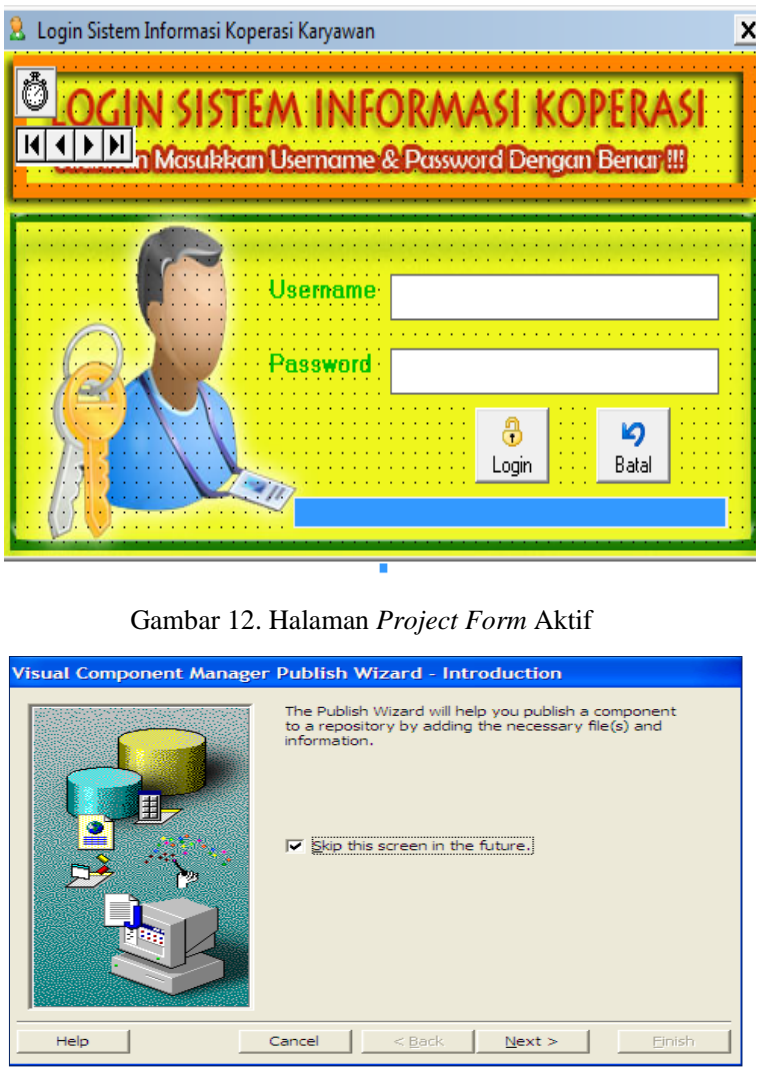

Gambar 13. Tampilan Jendele Introduction

3. Berikutnya akan ditampilkan jendela Select a Reporsitory/ Folder, (Gambar 14) yang digunakan untuk membuat folder hasil lokasi kompilasi sistem, klik tombol Next.

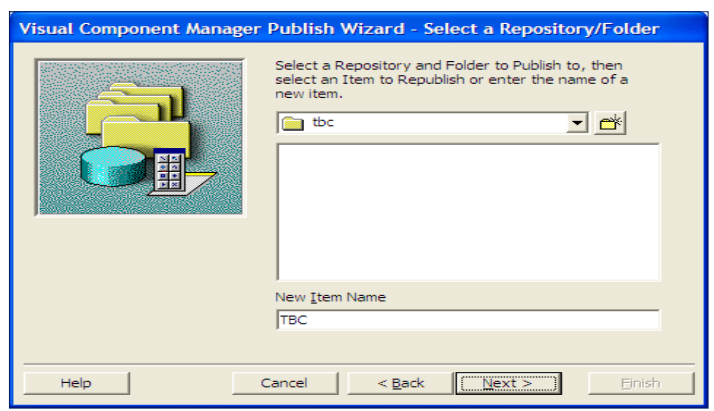

Gambar 14. Tampilan Jendela Select a Reporsitory/Folder

4. Muncul jendela Title and Properties lalu penulis lakukan pengaturan seperti terlihat pada Gambar 15 di bawah ini, lalu klik Next.

5. Muncul jendela More Properties seperti terlihat pada Gambar 16 di bawah ini, kemudian klik Next.

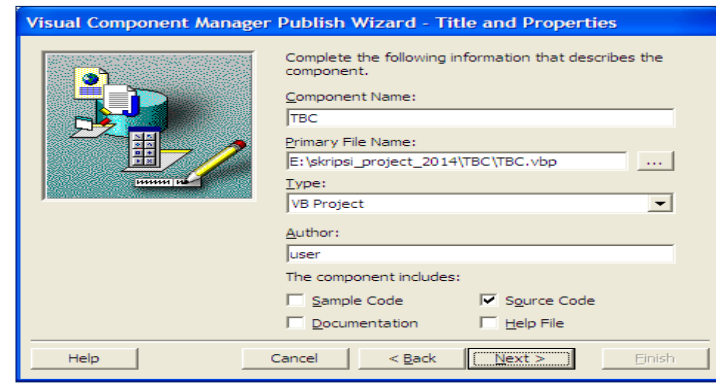

Gambar 15. Tampilan Jendela Title and Properties

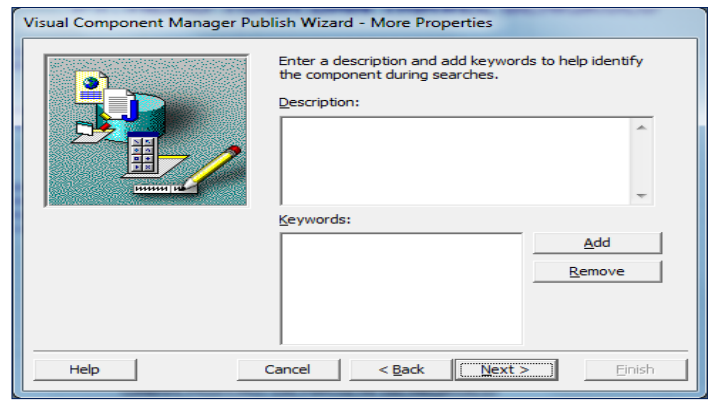

Gambar 16. Tampilan Jendela More Properties

6. Muncul jendela Select Additional File (s) seperti terlihat pada Gambar 17 di bawah ini, kemudian klik Next.

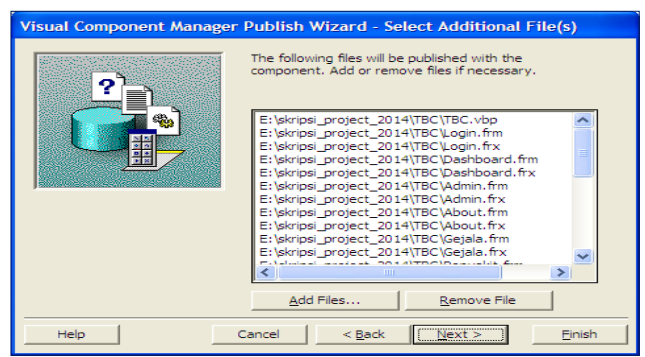

Gambar 17. Tampilan Jendela Select Additional File (s)

7. Muncul jendela COM Registration seperti terlihat pada Gambar 18 di bawah ini, kemudian klik Next.

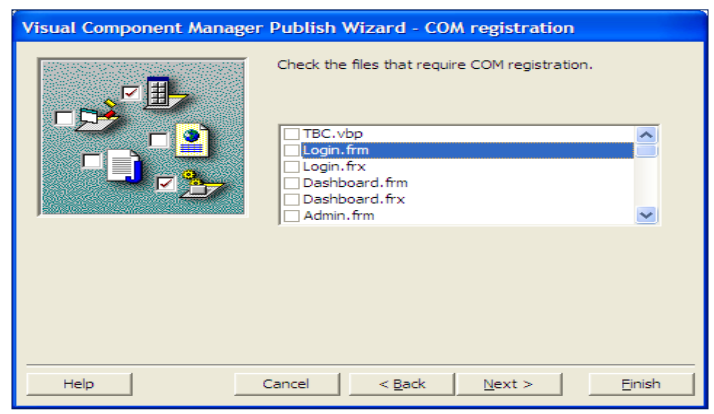

Gambar 18. Tampilan Jendela COM Registration 
Jurnal Pseudocode, Volume V Nomor 2, September 2018, ISSN 2355-5920, e-ISSN 2655-1845 www.ejournal.unib.ac.id/index.php/pseudocode

8. Muncul jendela Finished untuk mengakhiri proses kompilasi seperti terlihat pada Gambar 19 di bawah ini, penulis memilih tombol Finish.

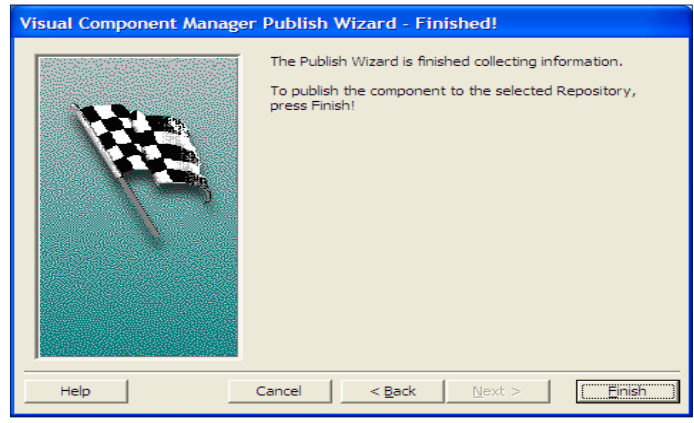

Gambar 19. Tampilan Jendela Finished

\section{HASIL DAN PEMBAHASAN}

Setelah Rancang Bangun Sistem Informasi Koperasi Karyawan Pada Badan Pusat Statistik (BPS) Kota Bengkulu berhasil dibuat, penulis melaksanakan pengujian aplikasi. Pengujian dilaksanakan terhadap 2 (dua) orang pengurus koperpasi dan 1 (satu) orang anggota koperasi kemudian diberi suatu angket berupa pertanyaanpertanyaan yang berhubungan dengan sistem administrasi yang telah diujikan. Adapun hasil dari pertanyaan-pertanyaan berupa angket tersebut dapat dilihat pada lampiran skripsi.

Berdasakan hasil isian angket kuisioner responden menunjukkan bahwa sistem informasi yang dibuat dapat berjalan dengan baik sehingga dapat diambil kesimpulan dari pengujian sebagai berikut:

\section{Pengujian login sistem.}

Dari hasil pengujian login system program dan isian angket kuisioner responden dapat dikatakan bahwa login system dapat berjalan dengan baik yaitu ketika memasukkan username dan password dengan benar maka seorang admin akan dapat login ke menu utama sistem yang dibuat sedangkan apabila username dan password yang dimasukkan salah maka akan mucul pesan "gagal login" sehingga admin tidak dapat login ke menu utama sistem.

\section{Tampilan Program}

Dari hasil pengujian tampilan program dan isiaangket kuisioner responden, ternyata tampilan Rancang Bangun Sistem Informasi Koperasi Karyawan Pada Badan Pusat Statistik (BPS) Kota Bengkulu sudah baik dengan adanya gambar latar belakang (background) kantor Badan Pusat Statistik (BPS) Kota Bengkulu.

3. Pengujian Kesesuaian Program dengan Lokasi Penelitian

Dari hasil pengujian program dan isian angket kuisioner responden terhadap kesesuaian program pada Rancang Bangun Sistem Informasi Koperasi Karyawan Pada Badan Pusat Statistik (BPS) Kota Bengkulu dengan lokasi penelitian telah sesuai dengan yang diharapkan.

4. Pengujian Isi Program

Pada pengujian isi program terhadap pemasukan data kedalam Rancang Bangun Sistem Informasi Koperasi Karyawan Pada Badan Pusat Statistik (BPS) Kota Bengkulu telah berjalan dengan lancar dan baik sesuai dengan yang diharapkan.

5. Pengujian Tombol-Tombol Proses

Pada pengujian terhadap tombol-tombol proses yang dibuat pada Rancang Bangun Sistem Informasi Koperasi Karyawan Pada Badan Pusat Statistik (BPS) Kota Bengkulu telah berjalan dengan lancar dan baik dikarena tombol proses yang digunakan menggunakan bahasa Indonesia.

\section{Persetujuan Penggunaan Program}

Pada pengujian persetujuan penggunaan program Rancang Bangun Sistem Informasi Koperasi Karyawan Pada Badan Pusat Statistik (BPS) Kota Bengkulu dinyatakan bahwa program 
Jurnal Pseudocode, Volume VI Nomor 1, Februari 2019, ISSN 2355-5920, e-ISSN 2655-1845 www.ejournal.unib.ac.id/index.php/pseudocode

yang dibuat disetujui untuk digunakan pada Koperasi Badan Pusat Statistik (BPS) Kota Bengkulu.

\section{KESIMPULAN}

1. Rancang Bangun Sistem Informasi Koperasi Karyawan Pada Badan Pusat Statistik (BPS) Kota Bengkulu yang telah selesai dibuat dapat memberikan alternative sistem dalam mendukung kinerja pengurus koperasi yang ada di Kantor Badan Pusat Statistik (BPS) Kota Bengkulu. Rancang Bangun Sistem Informasi Koperasi Karyawan Pada Badan Pusat Statistik (BPS) Kota Bengkulu dibuat dengan menggunakan bahasa pemrograman Visual Basic 6.0.

2. Secara umum hasil dari pembuatan Rancang Bangun Sistem Informasi Koperasi Karyawan Pada Badan Pusat Statistik (BPS) Kota Bengkulu memiliki menu input data terdiri: data anggota, data pengajuan pinjaman, data pinjaman disetujui, data simpanan dan data angsuran. Proses pemasukan data terhadap Rancang Bangun Sistem Informasi Koperasi Karyawan Pada Badan Pusat Statistik (BPS) Kota Bengkulu yang dilakukan dapat memberikan laporan berupa laporan anggota koperasi, laporan data simpanan per bulan, laporan data pinjaman per anggota, laporan data simpanan per anggota dan rekapitulasi pinjaman koperasi karyawan.

\section{REFERENSI}

[1] Hanif Al Fatta, 2007, Analisis dan Perancangan Sistem Informasi Untuk keunggulan Bersaing Perusahaan dan Organisasi Modern, Andi Yogyakarta, 212 halaman.

[2] Andri Kristanto, 2007, Perancangan Sistem Informasi dan Aplikasinya, Gava Media, Yogyakarta, 171 halaman.

[3] -------------, Undang Undang Nomor 17 Tahun 2012 tentang Perkoperasian. 